\title{
Geomorphological facilities and constraints in urban expansion of Craiova city
}

\author{
Claudia-Daniela Albă, Oana Mititelu-Ionuş, Sandu Boengiu \\ Department of Geography \\ University of Craiova \\ Craiova, Romania
}

\begin{abstract}
Since the appearance of the first cities, the landforms have represented a prime determinant in urban establishment and expansion, materializing either in a favourable element (river valleys, depressions), or in a restrictive one (mountain slopes, lands affected by landslides, floods or earthquakes). The urban planning and expansion involve the use of urban geomorphology, thus requiring geological and geomorphological analyses of the land and the dynamics monitoring of natural and anthropic processes that occur.
\end{abstract}

This study presents the territorial expansion of the Craiova city area in the geomorphological context induced by the river Jiu land form, in the period $1977-2017$. The visual perspective of the territorial expansion dynamic is performed with ArcGIS10, using multi-temporal satellite images from databases such as Landsat, CLC Europe, Google and topographical maps. There are also presented the morphometric and morphographic analyses of territory synthesized in indicators and specific maps (hypsometry, declivity, aspect).

The review of the territorial expansion of the last 40 years, correlated with the study of propitious geomorphological elements, the constraints generated by nature and the interpretation of the geomorphological indicators, transposes in tools necessary for a more efficient development and planning of Craiova's urban space.

Keywords- urban geomorphology; urban expansion; Craiova

\section{INTRODUCTION}

"An understanding of geomorphology, the science of landforms and earth surface processes, is essential to urban development. People need to know the ground they build on and to be aware of risk of flooding, subsidence, landslide, volcanic activity, earthquakes and erosion” [1]. In 1976, R.U. Cooke considered that the two important ways in which urban geomorphology could be useful for the management and development of urban areas were: the assessing of the potential resources and the suitability of land use in urban development and the monitoring geomorphological process - systems response during and after the urban development, the aim being to establish a theoretical framework and values used in management strategies and the involvement in making some projections that may occur in connection with urban expansion [2] "Urban geomorphology examines the geomorphic constraints on urban development and the suitability of different landforms for specific urban uses; the impact of urban activities on earth surface process, especially during construction; the landforms created by urbanization, including land reclamation and waste disposal; and the geomorphic consequences of the extractive industries in and around urban areas" [3, 4]. "Local landforms have played a central role throughout history in the choice of sites for settlements and their further development has often been influenced by regional geomorphology [5].

\section{THE STUDY AREA}

Situated in the south of Romania (Fig.1), in the centralsouth area of South West Oltenia Development Region, the City of Craiova is bordered by the folowing geographical coordinates: $44^{\circ} 16^{\prime} 05^{\prime \prime}$ and $44^{\circ} 22^{\prime} 43^{\prime \prime}$, north latitude and meridians $23^{\circ} 42^{\prime} 28^{\prime \prime}$ and $23^{\circ} 54^{\prime} 20^{\prime \prime}$ east longitude. The intersection of the European roads E70 (Spain - Georgia), E79 (Hungary - Greece) and E574 (Craiova - Bacău) mark the center of the city.

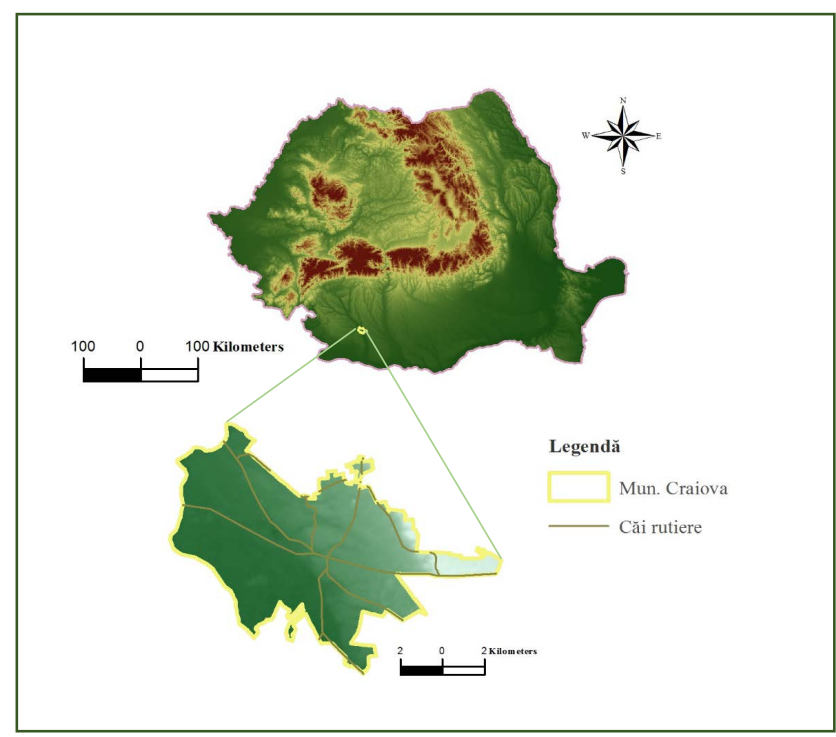

Fig. 1. The localization of the study area on Romania map

The administrative territory has a maximum extension on the west - east direction of $15.7 \mathrm{~km}$, the most part of it on the Jiu terraces and a minimum extension on the northsouth direction, of $5.2 \mathrm{~km}$, covering a surface of $81.96 \mathrm{~km}^{2}$.

Within the borders of the city are included natural limits such as the Jiu river (western border) and its tributary Amaradia, which forms the northern border. The settlement was developed at the contact between Getic Piedmont and Romania Plain, benefitting from the fertility of the Jiu valley and protected by the hills from the west 
(Bucovăt hill) and a swampy area in southern-east side. The landscape resulted behind the movement of the Jiu river towards west (five steps of terraces) influenced both the location and the further extension of the settlement.

The first human communities in the area of the current city are associated with the Neolithic Age (6000-2500 B.C.), then there is evidence of permanence of the settlement like village, then regional fair that included in its perimeter the villages from surroundings, too and since 1582 Craiova has been called a city [6].

\section{THE MORPHOMETRY AND GEOMORPHOGRAPHY OF THE STUDY AREA}

In addition to the analysis of the territory, the study of topographic maps (topographic military map 1: 25.000, published in 1975; topographic military map 1: 100.000, published in 1996) and the written materials about the natural aspects of the area, we used for this study the ArcGIS 10.5 software, for the interpretation of data provided by the COPERNICUS programme, which is managed by the European Commission. The Digital Elevation Model over Europe (EU-DEM) represents a hybrid product based on SRTM and ASTER GDEM data. The dataset which covers Europe was published on 20 April 2016, offering 1992 tiles at 4000 x 4000 pixel realized at a $25 \mathrm{~m}$ resolution.

Regarding altitude, the city of Craiova appears like an amphitheater that starts at $70 \mathrm{~m}$ altitude, on the west side and extends gradually until $199 \mathrm{~m}$ in east side. The minimum elevation, $69 \mathrm{~m}$ is recorded in the south-west extremity, in the flood-plain terrace of Jiu, at the contact with the village Balta Verde. Between these extremities (east north-eastern side and west south-west side) there results a difference of $129 \mathrm{~m}$. Approximately $40 \%$ of the city surface is underneath $85 \mathrm{~m}$ contour, beyond the hypsometric step of $180 \mathrm{~m}$ being only a very small area the airport area (the east extremity).

The lower terraces are covered with surfaces with a very low declivity (under $3^{\circ}$ ), the only exception being the Tineretului Park, located in the flood-plain terrace, where there are registered slopes between $3^{\circ}-5^{\circ}$. At the linkage with the medium terraces, the slope increases to $8^{\circ}$, and the superior terrace presents predominant surfaces with a $10^{\circ}-$ $11^{\circ}$ slope.

In contrast with the left bank, with terraces on which the city extended, the right bank of Jiu, without terraces, includes areas with $10^{\circ}-33^{\circ}$ slope, presenting a low pretability for urban expansion.

In the northern half of the medium terraces there can be distinguished a succession in the slopes' aspect: southsouth-west, then north-northeast-east, the southern side of medium terraces being characterized by the homogeneity in the exhibition of slopes. In the upper terrace the most slopes have a pitch towards north (shadowed slopes), north-west (semidarkness) and south-west.

The five terraces formed by Jiu in its movements towards west are covered by sand dunes which give it a slightly wavy aspect. The lithological substrate is differentiated according to the level of the terraces: the flood plain terrace and the lower terrace - clays, silts, sandy silts, gravels, in medium terraces predominant sands with gravel, partially covered with loess powder [7]. The western slope of the Jiu, with a more pronounced slope, is composed of the loess-like deposits, sands, gravels and reddish clays, favoring linear erosion and mass movement [7].

\section{THE URBAN EXPANSION OF CRAIOVA}

The visual perspective of the expansion dynamic for urban constructions was realized using ArcGIS 10.5, by the interpolation of multitemporal satellite images. To compare expansion of the built areas in different moments there were used the data mentioned in Table 1, but the graphical representation of results (Fig. 2) was simplified for an easy view.

TABLE I. DATA USED FOR THE VISUAL PERSPECTIVE OF THE EXPANSION DYNAMIC

\begin{tabular}{|l|l|l|}
\hline \multicolumn{1}{|c|}{ SATELLITE IMAGES } & \multicolumn{1}{c|}{$\begin{array}{c}\text { Date of } \\
\text { acquisition }\end{array}$} & \multicolumn{1}{|c|}{ Source } \\
\hline Landsat 2, MSS1-5 (100 m) & 09. sep.1977 & USGS \\
\hline Landsat / Copernicus & $31 . d e c .1984$ & Google Earth \\
\hline Landsat / Copernicus & 31. dec.1987 & Google Earth \\
\hline Landsat 5, TM (50 m) & 01. aug.1992 & USGS \\
\hline Landsat / Copernicus & 31.dec.2001 & Google Earth \\
\hline CLC2006 (100m) & Version 13 & EEA \\
\hline Landsat / Copernicus & 31.dec.2009 & Google Earth \\
\hline Digital Globe / CNES / Astrium & 01.feb.2017 & Google Earth \\
\hline
\end{tabular}

Since the establishment of the hearth settlement, the place geomorphology was an important factor, the settlement being established on the left bank of the Jiu, characterized by terraces, in total opposition to the right bank, which is steep and with frequently occurring processes of undermining and collapse [7].

Before the period to which this study is focused on (1977 - 2017), the expansion of the settlement was an asymmetric one, as shown in Map of Specht (1791) with an tentacular extension only on the east side (on medium terraces of Jiu), the western side of the main road along which it was formed, leaving only with a linear expansion. Lack of the corresponding extension on the west side was determined by the swamp flood plain, a remnant of the former meanders and abandoned courses of the Jiu, results of its movement westward. The swamp areas from the western and southern part of the city (lower terraces) represented not only a restriction in urban development, but also an unhealthy environment and a source of and epidemics, which determined the drainage and sewerage slough and marshes in the late nineteenth century and early twentieth century. But even after the draining slough and sewage water, in the period considered particularly since 1977, the expansion of urban construction is significant on upper terraces, in the detriment of the flood plain terrace.

From the constructed surface point of view, the dynamic in the mentioned period had a permanent expansion, from $27.16 \mathrm{~km}^{2}$ in $1977,42.45 \mathrm{~km}^{2}$ in 1987 , $61.31 \mathrm{~km}^{2}$ in 2009 , currently the constructed surface being of $73.02 \mathrm{~km}^{2}$. Compared with 1977, when the built area covered mainly terraces II and III, and was situated between altitudes of 75 and $120 \mathrm{~m}$, currently expanding urban housing has extended between altitudes 70 and 195 $\mathrm{m}$. In the floodplain terrace the expansion of construction 
is straighter along the road, but on the terraces IV and V the expansion of buildings is uniformous and pronounced.

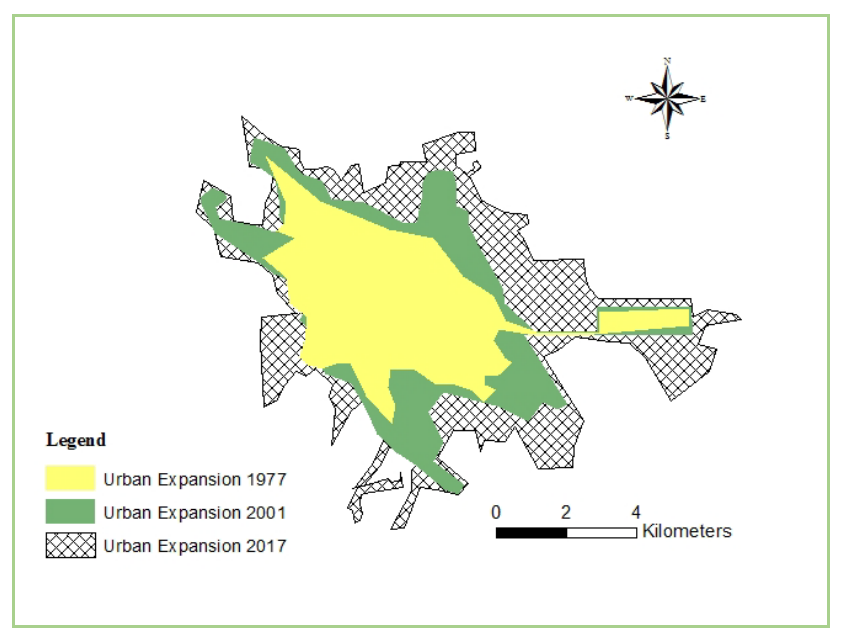

Fig. 2. The expansion of the built environment

\section{CONCLUSIONS}

The area situated on the left bank of the Jiu, between the Getic Piedmont and Romanian Plain, defined by an altitudinal gradually progress from 70 to $190 \mathrm{~m}$, on W-E direction, with a very low slope, has facilitated the extension of the settlement. The right Jiu bank, with a slope between $10^{\circ}-33^{\circ}$, and with a potential risk of land slide was not an attractive factor in the urban expansion. The development on the west - east direction was also conditioned by the potential hydrological risk from the south.

The areas that have extensive urban construction during 1977 - 2017 consist predominantly of the upper terraces of the Jiu with a reduced average slope, under $5^{\circ}$, and less on the flood-plain terrace, which presents an unfavorable lithological composition.
The result of this study shows a predominantly expansion on the eastern direction, the largest expansion was recorded in the last period (2009 - 2017), with a trend of expansion of the area to the east in the future, too.

The disproportionate urban sprawl, predominantly on one side of the city, required the focus of administrative efforts, too, in achieving the general infrastructure and public utilities in the area of where constructions have been developed.

The correlation of a geomorphic study with a historical perspective on the expansion, is an important tool in the anticipation of future needs, having the aim to increase the quality of living and life in general, but also directing the urban expansion towards the balanced used of the land.

\section{REFERENCES}

[1] I. Douglas, and P. James, Urban Ecology: An Introduction. Taylor \& Francis, 2014

[2] R.U. Cooke, “Urban Geomorphology”, The Geographical Journal, 142(1), pp. 59-65, 1976.

[3] I. Douglas, Cities: An Environmental History. I.B. Tauris, 2013.

[4] I. Douglas, D. Goode, M. Houck, and R. Wang (Eds.), The Routledge Handbook of Urban Ecology. Routledge, 688 p., 2010.

[5] G.D. Bathrellos, "An overview in urban geology and urban geomorphology”, Bulletin of the Geological Society of Greece, vol. 40, pp. 1354 -1364, 2007.

[6] T. Georgescu, C. Barbacioru, and F. Florea, Istoria Craiovei. Craiova: Editura Scrisul Românesc, 289 p., 1977. (in Romanian)

[7] I. Irimus, and S. Boengiu, "Substratul morfo-litologic" în "Strategi de dezvoltare urbană. Municipul Craiova”, P. Cocean, Ed. 2011. Presa Universitară Clujeană: Cluj Napoca, 2011, pp. 9-13. (in Romanian) 